\title{
WATER TREATMENT PLANT FOR A ROLLING - MILL TRAIN
}

GoicoecheA, I. \& MARTineZ, S.

Abstract: Water treatment plants consist in systems where water is treated and subjected to diverse processes based on the intended industrial use of the water. In the case of treatment plants for water from the cooling of continuous rolling-mill trains, the elimination and separation of oils, filtration, cooling or the thickening or dehydrating of sludge are some of the processes to which the water may be subjected. In order to design the process we use a series of pre-established technical requirements, such as, for example, thermal differences needed to cool the fluid, speed, flow, and pressure at specific points and the different concentrations of materials permitted in the water. In addition to complying with said requirements we attempt to optimise the process applying the following criteria:

- Recirculation of the total flow which passes through the lines.

- Reduced water consumption.

- Improving, as far as possible, the quality of the water recirculated through the train.

- Reducing maintenance costs, installation project costs and equipment costs.

Key words: waste - water purification plant, rolling - mill train, water treatment
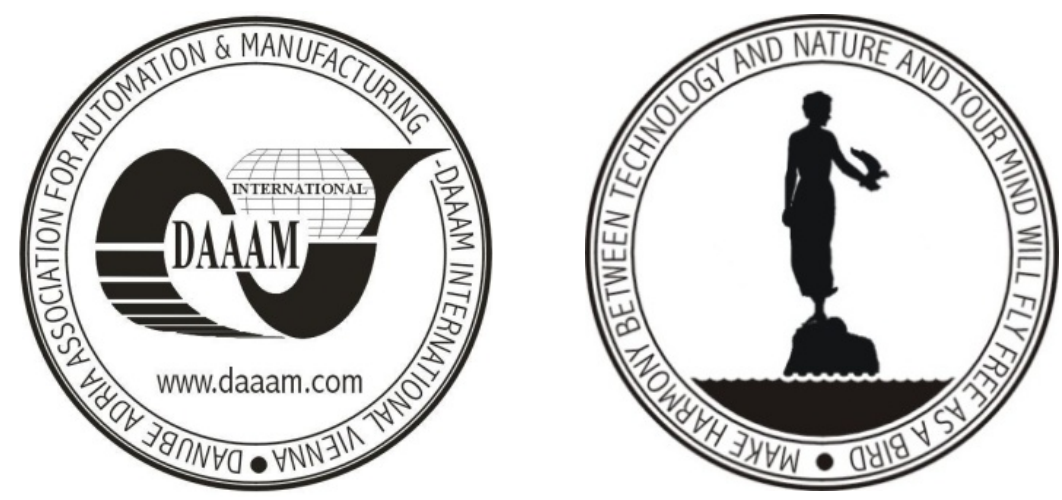

Authors' data: Univ.Prof. Ing. Dr.Goicoechea, I[tziar]; Ing. Martinez, S[ilvana], University of Vigo, E.T.S.Industrial Engineers. Campus Lagoas Marcosende s/n Vigo. Spain, igoicoechea@uvigo.es

This Publication has to be referred as: Goicoechea, I[tziar] \& Martinez, S[ilvana] (2009). Water Treatment Plant for a Rolling-Mill Train, Chapter 94 in DAAAM International Scientific Book 2009, pp. 965-976, B. Katalinic (Ed.), Published by DAAAM International, ISBN 978-3-901509-69-8, ISSN 1726-9687, Vienna, Austria DOI: 10.2507/daaam.scibook.2009.94 